\title{
The pollen season dynamics and the relationship among some season parameters (start, end, annual total, season phases) in Kraków, Poland, 1991-2008
}

\author{
D. Myszkowska • B. Jenner • D. Stępalska • \\ E. Czarnobilska
}

Received: 25 March 2010/ Accepted: 9 December 2010/Published online: 29 December 2010

(C) The Author(s) 2010. This article is published with open access at Springerlink.com

\begin{abstract}
The dynamics of 15 taxa pollen seasons in Kraków, in 1991-2008 was monitored using a Burkard volumetric spore trap of the Hirst design. The highest daily pollen concentrations were achieved in the first half of May, and they were caused mainly by Betula and Pinus pollen. The second period of the high concentrations took place from the middle of July to the end of August (mainly Urtica pollen). Tree pollen seasons were shorter (18-24 days) in comparison with the most herbaceous pollen seasons (73-89 days), except at Artemisia and Ambrosia seasons (30 and 24 days, respectively). The season phases (percentyles) of the spring and late-summer taxa were the most variable in the consecutive years. The highest annual sums were noted for Urtica, Poaceae (herbaceous pollen seasons) and for Betula, Pinus, Alnus (tree pollen seasons), and the highest variability of annual
\end{abstract}

D. Myszkowska ( $\square) \cdot$ E. Czarnobilska

Department of Clinical and Environmental Allergology, Jagiellonian University Medical College, Śniadeckich 10, 31-531 Kraków, Poland

e-mail: dmyszkow@cm-uj.krakow.pl

B. Jenner

Department of Clinical and Environmental Toxicology, Jagiellonian University Medical College, Złotej Jesieni 1, 31-826 Kraków, Poland

D. Stępalska

Institute of Botany, Jagiellonian University,

Kopernika 27, 31-501 Kraków, Poland totals was stated for Urtica, Populus, Fraxinus and the lowest for Ambrosia, Corylus, Poaceae. For the plants that pollinate in the middle of the pollen season (Quercus, Pinus and Rumex), the date of the season start seems not to be related to the season end, while for late pollen seasons, especially for Ambrosia and Artemisia, the statistically negative correlation between the start and the end season dates was found. Additionally, for the most studied taxa, the increase in annual pollen totals was observed. The presented results could be useful for the allergological practice and general botanical knowledge.

Keywords Aeropalynological monitoring · Pollen season $\cdot$ Season parameters $\cdot$ Kraków $\cdot$ Poland

\section{Introduction}

The aerobiological observations are focused on the pollen and fungal spore concentrations in the air. The results of these analyses are of a great help for some scientific disciplines such as phenology, climatology, ecology, agriculture, forensics, and allergology (Weryszko-Chmielewska 2007). Since the first half of the twentieth century, the pollen monitoring has been performed in Europe; nowadays more than 500 monitoring stations in 49 countries joined the European Aeroallergen Data Base (www.ean.polleninfo.eu/Ean; www.polleninfo.org). 
In Poland, the first interest in a study on pollen and fungal spore concentrations in the air took place in 1939, when the first calendars of flowering and pollination of allergenic plants in the area of Kraków were presented (Obtułowicz 1939). In other Polish cities, the phenological and aerobiological observations primarily using the gravimetric method took place. In nineteenths of the twenteeths century, the intensive studies came into being in large university centres (Stach 2000; Latałowa et al. 2002; Kasprzyk 2003; Piotrowska 2006; Chłopek 2007).

In Kraków, the development of the aerobiological studies was associated with a high level of palynology and the practical application of monitoring results in allergology (Obtułowicz et al. 1990, 1991, 2002; Myszkowska et al. 2002). In 1982, the gravimetric analyses were initiated, while the volumetric monitoring started in 1989 (Szczepanek 1994). Aerobiological monitoring is performed during the whole year and about 40 taxa are recognized. The very important aim of the station work is to apply pollination data of allergenic plants for medical practice in the Małopolska region (www.krakow.pios.gov.pl). Generally, in Poland about $30 \%$ of the population suffer from allergic rhinitis (Samoliński 2008). The results of the latest study performed in Kraków showed that in two groups of young patients with allergy symptoms (1628 aged 7 years, 1721 aged 16 years), allergic rhinitis symptoms were reported by $29.5 \%$ (7-yearolds group) and $25.8 \%$ (16-year-olds group) of the patients, and these symptoms were confirmed by positive skin-prick tests and increased sIgE level in $46.6 \%$ of the 7 -year-olds group and in $58.2 \%$ of the 16 years old group (Sak-Rusek et al. 2009).

Referring to the publications discussing both the short- and long-term series pollen analyses, it is stated that the specific pattern of these analyses occurs. The authors analyze the basic seasonal parameters, such as the beginning and the end of the pollen season, the season duration, the annual pollen total, and the peak concentration (Spieksma et al. 1995; Emberlin et al. 2000; WeryszkoChmielewska et al. 2001; Kasprzyk et al. 2004; Weryszko-Chmielewska 2006). The pollen season dynamics is often explained by the meteorological conditions, which influence the majority of the season parameters (Rodriguez-Rajo et al. 2004; Emberlin et al. 2007; Stach et al. 2008).
Apart from the seasonal parameter analysis, the authors of the current study try to estimate the relationship among some of the parameters. This analysis seems to be helpful to forecast the dynamics of pollen seasons and to construct the predictive models. The similar approach was reported by García-Mozo et al. (2002), Orlandi et al. (2009).

The main aim of the study was to analyze the pollen season dynamics and to explain the relationship among the chosen parameters in Kraków, in 1991-2008. The aim was presented in the following problems:

- analysis of the variability of consecutive pollen season phases for 15 taxa pollen,

- analysis of the variability of annual pollen totals for 15 taxa pollen,

- estimation of the relationship between the pollen season start and end dates for the examined taxa,

- estimation of the relationship between the year of observation and the pollen season start,

- estimation of the relationship between the year of observation and the annual pollen total.

\section{Materials and methods}

\subsection{Study site}

Kraków (220 $\mathrm{m}$ a.s.1., $\left.50^{\circ} 04^{\prime} \mathrm{N}, 19^{\circ} 58^{\prime} \mathrm{E}\right)$ is located in the Małopolska province (Southern Poland) and surrounded by farmlands and forests. To the north of Kraków, farmlands occur with small forest communities. To the south and east of Kraków, there are roughly equal areas of farmlands and forests. To the west of the city, forest communities prevail.

Kraków and Poland are influenced by the air masses of the polar-maritime origin coming from over the Northern Atlantic which bring thaw, increase in cloudiness and snow in winter and chilling, increase in cloudiness and rainfall in summer. Mean January and July temperatures in Kraków are -3.4 and $17.6^{\circ} \mathrm{C}$, respectively, and mean annual sunshine duration per day is $3.9 \mathrm{~h}$, although from April to September it is $5.7 \mathrm{~h}$ (Woś 1999). Mean annual precipitation is approximately $700 \mathrm{~mm}$. The highest rainfall level is recorded in summer (June, July, August). In the annual cycle, about $40 \%$ of the rain falls in these months in Poland. Mean annual 
humidity is $79 \%$ and wind from westerly direction prevails. Mean wind velocity is relatively low, about $2.9 \mathrm{~ms}^{-1}$ (Woś 1999).

\subsection{Palynological data and statistics}

Pollen concentration has been monitored using the volumetric sampler (Burkard trap in 1991-2003, Lanzoni trap in 2004-2008) located on the roof of the building ( $20 \mathrm{~m}$ above ground level) situated in the center of the Kraków city. Airborne pollen grains were sampled continuously, 12 months a year during 1991-2008. The Melinex tape used for catching pollen grains was replaced every Tuesday at 8 a.m. and cut into segments corresponding to $24 \mathrm{~h}$ periods. Two different counting methods have been employed. From 1991 to 1999, pollen grains were counted along 12 latitudinal transects. From 2000 to 2008, this method was changed into counting along 4 longitudinal transects according to the method used by the Spanish Aerobiology Network (REA; Carinanos et al. 2000). Daily average pollen counts were expressed as pollen grains per cubic meter of air.

In the study, 15 taxa were taken into account because of their allergenicity or great amount in the air, 9 tree and shrub taxa (Alnus, Corylus, Betula, Populus, Fraxinus, Quercus, Pinus, Picea, Salix), and 6 herbaceous taxa (Poaceae, Plantago, Rumex, Urtica, Artemisia, Ambrosia). Pollen seasons were calculated using the 90 and $95 \%$ methods for the start and end of the season, respectively. The start of the season was defined as the date when $5 \%$ of the seasonal cumulative pollen count was trapped, and the end of the season as the date when $97.5 \%$ of the seasonal cumulative pollen count was reached (Jato et al. 2006). This connected method was chosen because of the great amount of species taken into analysis. From the preliminary findings, it was concluded that the percentile used to define the start of the season should be somewhat higher than the percentile used for calculating end of the season. This is why the "asymetrical percentiles" were used.

The percentage values from total yearly accumulated (5) 25-50 and 75 (97.5)\% were used as the consecutive season phases. The variability of the season phases was analyzed.

Statistical analysis was performed using the Statistica program version 8.0 (StatSoft, Inc. 1984-2008). To estimate the relationship among seasonal parameters, the correlation and regression analyses and the descriptive (mean, median, quartiles, standard deviations, min, max) statistics were used. Correlation analysis can be thought as a method of studying two-dimensional normal distribution. Such a distribution has the center defined by means of both distributions. The observations used to calculate the two means should be scattered around the center, and one may use the correlation analysis to encircle an area (for correlated data it is an ellipse) containing given fraction of these points (e.g., 95\%). This extended application of the correlation analysis was used in our paper. The data used in the correlation and regression analyses of the dates (the number of a day in a year for the beginning and end of a given phase of a season) were not transformed. However, the annual pollen totals were logarithmically transformed (natural logarithm) before they were correlated with a year of observation.

\section{Results}

Analyzing the pollen season dynamics of all the studied taxa, the similar shape of the pollen curves for particular seasons was found. The pollen curve built on the basis of mean annual concentrations showed the general course of the pollen concentration occurrence during the season. The highest daily concentrations were recorded in the first half of May (16-18 week), especially in 2001, 2003, and 2008 (Fig. 1). The second period of the high concentrations took place from the middle of July to the end of August (e.g., in 1997, 1998; Fig. 1).

The Corylus pollen grains appeared as the first at the beginning of the year. The start of the Corylus pollen season was noted in the 45 day of the year (mean value: 13 February; min: 11 January, max: 25 March, SD $=22.1$ days). The last occurring taxa were as follows: Ambrosia (mean date of the season end: 245 day of the year $=1$ September, min: 13 August, max: 6 September, $\mathrm{SD}=6.3$ days) and Plantago (mean: 237 day of the year $=24$ August, min: 15 Aug, max: 3 September, $S D=5.6$ days). Tree pollen seasons were shorter (Fraxinus: 18 days; Populus: 22 days; Betula: 24 days) in comparison with the most herbaceous pollen seasons (Plantago: 89 days; Rumex: 79 days; Poaceae/Urtica: 73 days). The pollen seasons of Artemisia and Ambrosia were 


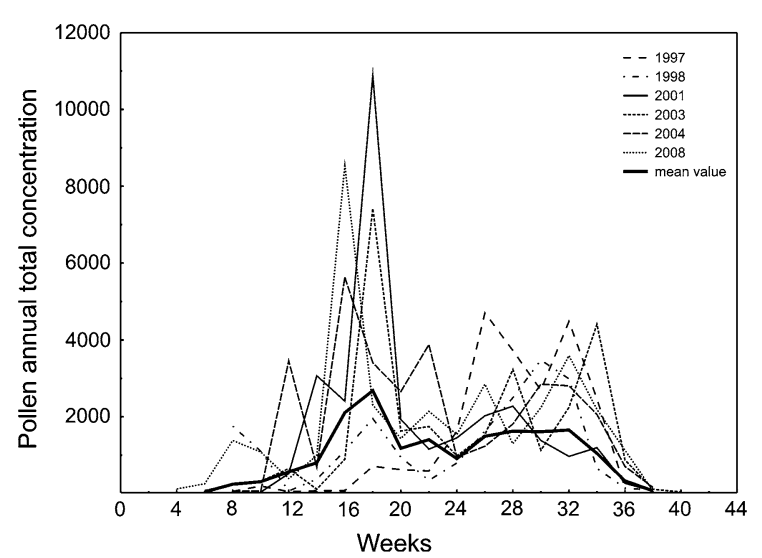

Fig. 1 The mean annual total (1991-2008) and the selected years with the highest annual totals

rather short, although they belong to herbaceous (30 and 24 days, respectively, Fig. 2).

The variability of the consecutive season phases showed the distinctive pattern. The dates of season phases of the early spring and late-summer taxa were more variable than those of taxa occurring from the beginning of April to the end of May (Fig. 3).

The annual pollen sum was calculated as a number of pollen grains in the defined pollen season, which means between 5 and $97.5 \%$. The highest annual sums were noted for Urtica, Poaceae (herbaceous pollen), and for Betula, Pinus, Alnus (tree pollen). The smallest annual totals were achieved by Ambrosia and Plantago and also by tree taxa, such as Picea, Populus, Corylus. The highest variability of annual totals was stated for Urtica, Populus, Fraxinus and the lowest for Ambrosia, Corylus, Poaceae (Fig. 4).

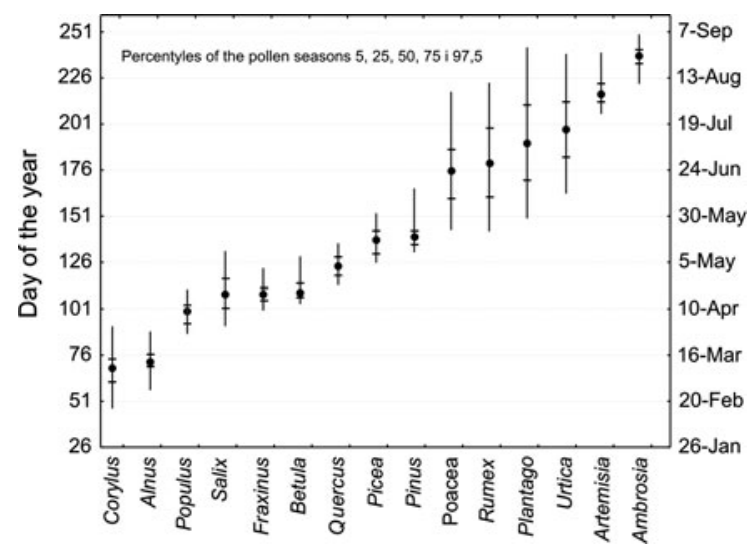

Fig. 2 The average dates of the season phases of the examined taxa
For the earliest pollinating taxa (Alnus and Corylus), the earlier pollen season start was associated with the earlier season end (coefficient of the regression line: day of a year for the end of the season $=$ slope*day of a year for the beginning of the season + constant + error was statistically significantly greater than 0 ). There is important that testing the significance of the regression slope is the same as testing the coefficient of correlation. Inside the ellipses, made by isolines of two-dimensional normal distribution, there should occur $95 \%$ of points indicating starts and ends of the season for particular taxa (Fig. 5). However, the value of the direction factor was lower than 1 (Fig. 6). This means that 1day delay in the start of the pollen season results in less than 1-day delay of its end (in other words seasons that begin earlier tend to be shorter). For the plants that pollinate in the middle of the pollen season (for instance Quercus, Pinus, Rumex), the date of the season start seems not to be related to the season end (Figs. 5, 6). For plants pollinating at the end of summer, like Ambrosia and Artemisia, the statistically negative correlation between the start and end season dates was found (the later pollen seasons start, the earlier they are over; Figs. 5, 6).

Comparing the relationship between the start and end of the pollen season (measured as coefficient of determination $r^{2}$ ) across different taxa, it can be said that this association is more evident for spring and late-summer plants than for plants pollinating between late spring and summer (Fig. 7).

Negative relationship between the year of observation and the pollen season start was found for Plantago, Poaceae, Populus, and Quercus, this means that the pollen seasons started earlier in the recent years (Table 1).

For most of the studied taxa, an increasing trend in annual pollen totals was observed across the observational period. The highest statistically significant positive correlations between the year of observation and the natural logarithm of annual total were calculated for Corylus, Picea, Salix (Table 1).

\section{Discussion}

The aim of the aerobiological observations is to define the pollen spectrum in a given region. The spectrum contains all pollen grains recognized in the 

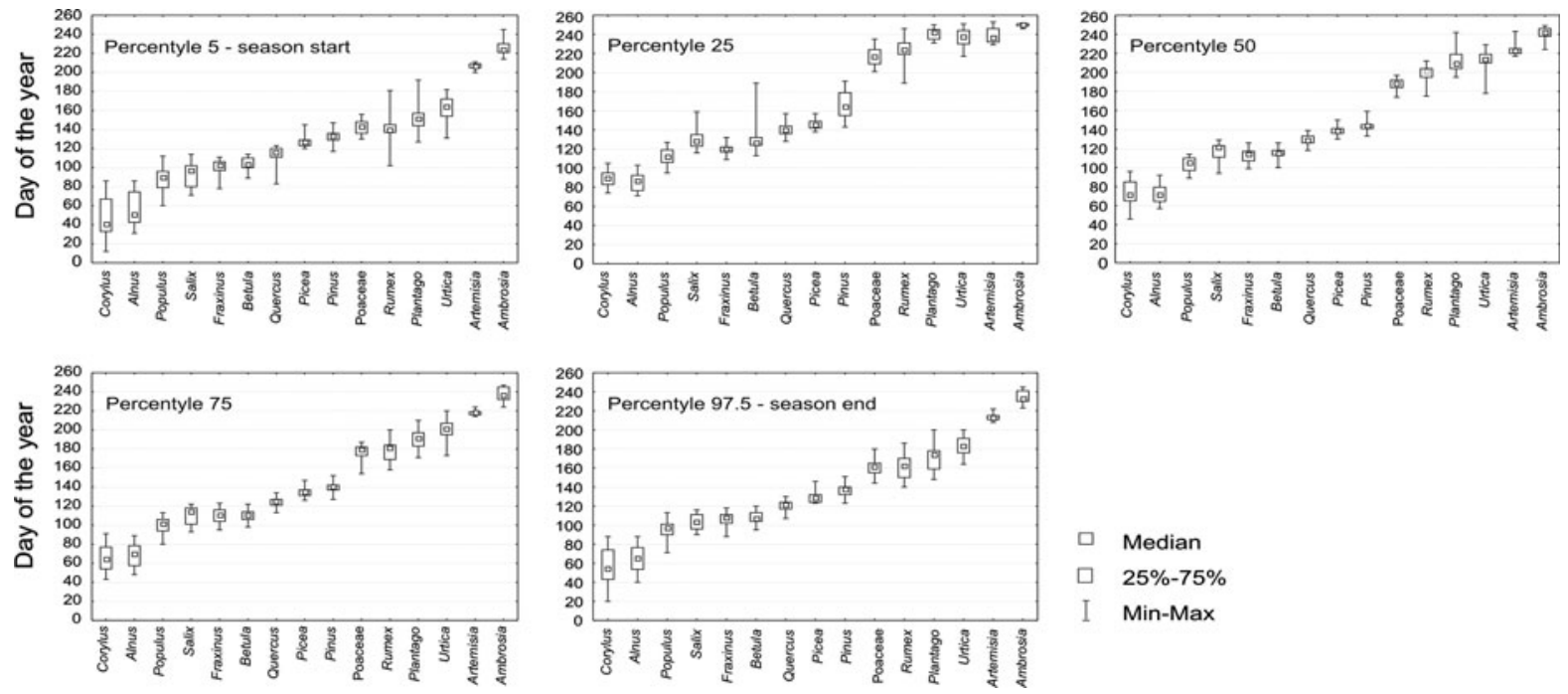

Fig. 3 The variability of the dates of the season phases

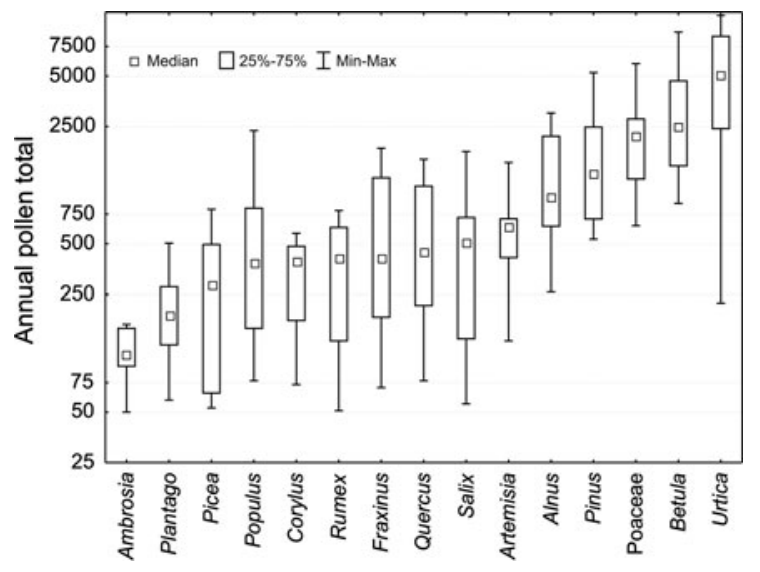

Fig. 4 The variability of the annual totals for the examined taxa

air samples, which came from both the local sources and the long-distance transport (Szczepanek 2003). Short data series (3-5 years) allow the scientists to study the pollen spectra and to make preliminary analyses of the pollen season occurrences (Stach 2006; Weryszko-Chmielewska and Piotrowska 2004; Weryszko-Chmielewska 2006). However, the long data series enable the aerobiologists to estimate the pollen seasons variability and to determine trends for the season parameters (Frei and Leuschner 2000; Spieksma et al. 1995; Emberlin et al. 2000, 2007; Latałowa et al. 2002; Stach et al. 2008).

Analyzing the pollen season dynamics, the highest concentrations were reached in the middle of May.

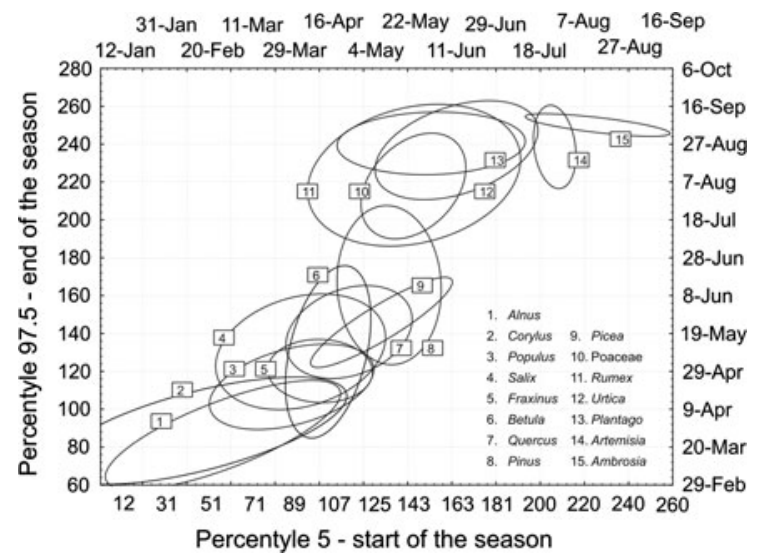

Fig. 5 The relationship between the start and end dates of a given taxon. The graphical presentation of this relationship for examined taxa

This spring peak concentration was caused by the high tree pollen concentrations of Betula and Pinus, which pollinate from the second half of April to the end of May. Both volumetric and gravimetric studies, performed in Kraków, showed that the percentage of Betula pollen in annual total was the highest (Szczepanek 1994; Myszkowska 2006; Myszkowska et al. 2007). Seven birch species occurring in Poland pollinate from the second part of April to the end of May. The most frequent are B. pendula Roth and B. pubescens Ehrh., which pollinates about 2 weeks later than B. pendula (Zając and Zając 2001; Seneta and Dolatowski 2007). 


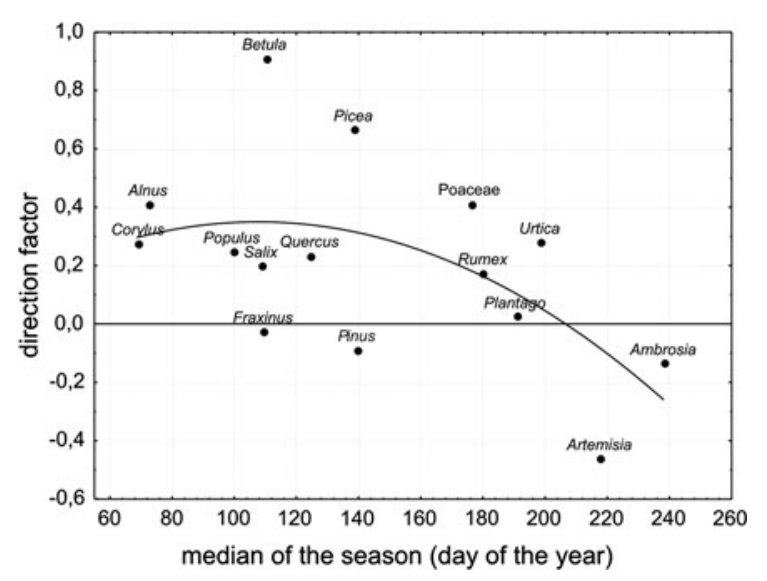

Fig. 6 The strength of relationship between the season start and end of the examined taxa with relation to the direction factors

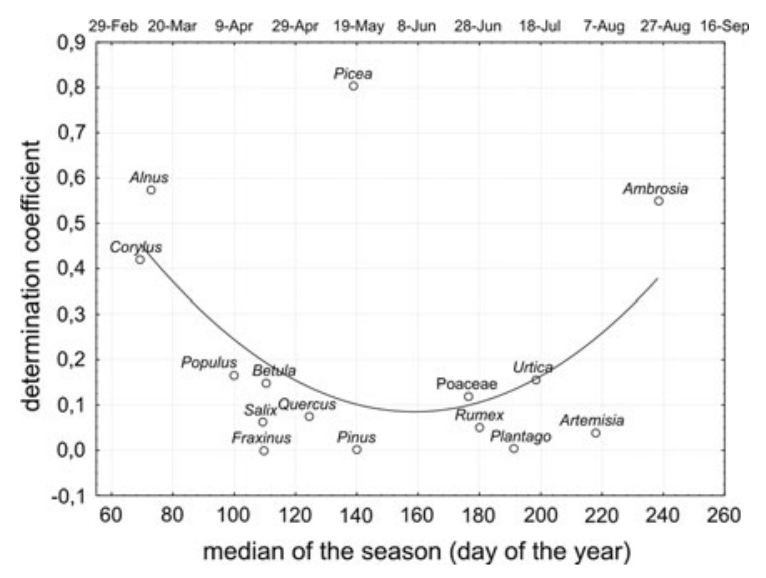

Fig. 7 The strength of relationship between the season start and end of the examined taxa with relation to the determination coefficient

In the study performed in Italy, the curve of the whole pollen season did not show the early spring tree seasons (Alnus, Corylus), which are responsible for the allergenic rhinitis symptoms in sensitive patients at the beginning of the year in Northern and Central Europe (D'Amato et al. 2007). Monitoring of Alnus, Corylus, and Betula pollen concentrations is really important for phenological observations and allergy treatments. The administration of initiation dose in the pre-seasonal specific immunotherapy (SIT) and the monitoring of the perennial immunotherapy in patients allergic to tree pollen allergens depend clearly on the tree pollen season start and peak pollen concentrations. According to EAACI standards, the immunotherapy should be applied dependently on the seasonal allergen exposition (Alvarez-Cuesta et al. 2006).

The second peak concentrations took place between 26 and 32 week of the year (from the half of July to the end of August) and were caused by the increase in Urtica pollen concentrations (more than $600 \mathrm{pgm}^{-3}$ ) and other herbaceous taxa, such as Poaceae, Artemisia, Plantago. In June (20-24 week), the pollen concentration was relatively low (Fig. 1); however, there was the main grass pollen season when more than $80 \%$ of the patients suffering from allergic rhinitis demonstrate allergy symptoms (Obtułowicz et al. 1990, 1991; Myszkowska et al. 2002; D'Amato et al. 2007). It is clearly stated that the whole-year dynamics analysis without detailed information about taxa pollen is not sufficient for the proper evaluation of the season dynamics. Similar results for the whole pollen season analysis were obtained for Lublin, where the highest pollen concentrations were noted in April, May, July, and August, but the lowest in June (Weryszko-Chmielewska and Piotrowska 2004).

According to Szczepanek (1994), herbaceous pollen seasons can be described as "long" (60-120 days), with the consecutive season phases occurring in similar time intervals. It is caused not only by Poaceae but by the number of species pollinating in a long time as well. In Poland, about 300 grass species occur that pollinate from April to September (Frey 2007). Generally, the herbaceous pollen seasons are more stable, and the variability of the following season phases is relatively low. Among the herbaceous taxa, only Artemisia and Ambrosia pollen seasons are of short seasons. They lasted on average 30 and 27 days, respectively, in Kraków, in comparison with 45 and 40 days in Poznań (Stach 2006; Stach et al. 2007), 43 and 54 days in Lublin (Weryszko-Chmielewska and Piotrowska 2004; Piotrowska and Weryszko-Chmielewska 2006), 43 and 30 days in Szczecin (Puc 2006).

Ambrosia pollen came to Kraków, in great part, from Slovakia and Ukraine (long-distance transport). This phenomenon was confirmed by using the "backtrajectory" analysis and analyzing the meteorological parameters' impact on pollen season concentration (Stępalska et al. 2002, 2008; Smith et al. 2008).

The knowledge of the pollen season duration is important from allergological point of view. In case 
Table 1 The relationship between the year of observation and the pollen seasons start, and the relationship between the year of observation and the ln of annual total for 15 taxa

\begin{tabular}{lll}
\hline Taxon & $\begin{array}{l}\text { Spearman's correlation } \\
\text { between the year of } \\
\text { observation and season } \\
\text { start }\end{array}$ & $\begin{array}{l}\text { Spearman's correlation } \\
\text { between the year of } \\
\text { observation and ln of } \\
\text { annual total }\end{array}$ \\
\hline Alnus & n.s. & n.s. \\
Ambrosia & n.s. & n.s. \\
Artemisia & n.s & $0.4841^{*}$ \\
Betula & n.s & $0.4847 *$ \\
Corylus & n.s & $0.8635^{* * *}$ \\
Fraxinus & n.s & $0.5762 *$ \\
Picea & n.s & $0.8873 * *$ \\
Pinus & n.s & n.s. \\
Plantago & $-0.5294 *$ & $0.4997 *$ \\
Poaceae & $-0.6389 * *$ & $0.5309 *$ \\
Populus & $-0.4872 *$ & $0.7067 *$ \\
Quercus & $-0.4886 *$ & $0.7379 * * *$ \\
Rumex & n.s & $0.7257 * * *$ \\
Salix & n.s & $0.8834 * * *$ \\
Urtica & n.s & $0.6794 * *$ \\
\hline Spearmat & sortion
\end{tabular}

Spearman's correlation test was used

Statistically significance: $\quad * p<0.05, \quad * * p<0.01$, $* * * p<0.001$

of short pollen seasons, the monitoring of SIT allows to avoid the accumulation of allergen dose and the high pollen concentration (natural allergen exposure) and even to omit the whole pollen season of the allergic taxon.

The peak concentrations of the majority of the taxa are achieved in short time, up to several days, and then the pollen season curves slowly go down (right asymmetry). It refers especially to the most tree taxa and to Artemisia and Ambrosia. In case of Betula and Pinus pollen seasons, $50 \%$ of the annual totals were achieved in 5-15 days that was associated with the type of pollen release from anthers (Szczepanek 2003). The study performed in seven monitoring centers in Poland in 1995-1996 showed that in most cases, $50 \%$ of the annual totals were reached before the middle of the pollen season (Kasprzyk et al. 2004). On the other hand, Latałowa et al. (2002), analyzing a 7-year data series of Betula pollen seasons in Gdańsk, showed that the first season phase (5-25\%) was achieved in 1-3 days and the 50\% in 4-5 days.
Depending on the taxon, the consecutive phases (percentyles) of the pollen season are achieved in different times. The most important is to predict the pollen season start (in the present paper: 5\%), because it is strictly associated with the allergy symptoms appearance, although the allergens may occur in the air even before the season start (Madeja et al. 2005). The Alnus and Corylus pollen seasons demonstrate the highest seasonal variability that depends on the changeable thermal conditions at the beginning of the year (Kasprzyk et al. 2004; Rodriguez-Rajo et al. 2004; Smith et al. 2007).

Some authors, analyzing the pollen season beginnings, try to define the influence of global warming on the pollen seasons dynamics (Newnham 1999; Donnelly et al. 2004; Stach et al. 2007). On the basis of a 15-year observation in Kraków, the statistically significant trend for season starts was not established except at Plantago, Poaceae, Populus, and Quercus pollen seasons. The seasons of these taxa started earlier in the studied period. Some authors stress the influence of the global climate change on the pollen season parameters, especially on the alder season start (Smith et al. 2007). In case of the birch pollen seasons, Emberlin et al. (2002) indicated the earlier and earlier pollen season start in five study centers in Western Europe, and only in the northern part of Europe (Kevo) the birch pollen seasons started later in the study period (1980-2000). Latalowa et al. (2002) did not find the earlier starting Betula seasons in Gdańsk in 1996-2004 years. In case of the grass pollen seasons, the start dates depend on the latitude (Emberlin et al. 2000), and especially in 13 monitoring stations in Western Europe, they are influenced by the North Atlantic Oscillation (NAO; Smith et al. 2009).

In the present paper, the relationship between the start and the end of the pollen season has been discussed. This seems to make the prediction of the pollen season dynamics and duration easier. In consequence, this information is useful for the specific immunotherapy monitoring. This relationship seems not to be general for all the studied taxa. It was found to be clear for spring taxa, with the high variability of the pollen season starts. The results of this study showed that the delay of pollen season starts shortened its duration, what well influenced the quality of life of allergic patients. Similar observations were made by Obrębska-Starklowa (1977), who 
found that the duration of the vegetative season depends on the start date. The earlier start dates are associated with the longer vegetation season.

The variability of annual totals is caused by the plant physiology and meteorological conditions in the previous and present years (Latałowa et al. 2002). This variability has an impact on the estimation of the pollen allergy treatment, which seems not to be objective without the simultaneous pollen data evaluation. The pollen concentration in a given year influences the allergy symptoms intensity (Obtułowicz et al. 2002). The lowest variability was found for Ambrosia, Corylus, and Poaceae pollen annual totals.

There was an increase in annual totals for most the studied taxa except at Alnus, Ambrosia, and Pinus. Similar results were found for Betula pollen in Kraków on the basis of an 11-year observation (1995-2005; Stach et al. 2008). Spieksma et al. (2003) indicated the statistically significant increase in the birch and oak pollen concentrations in several study sites in the Western Europe on the basis of the long series data, which was higher in the centers with the lower annual totals. It was explained by the lower annual total variability. In Kraków, the increase in birch annual total was estimated, in spite of the high annual concentrations. Probably, this increase was not caused by the increasing number of birch plants in Kraków and its neighborhood. Similarly, the increase in Urtica annual total was showed, in spite of the high annual variability. On the other hand, followed by the earlier papers, the increase in the ragweed pollen concentration was not indicated (Stępalska et al. 2008). However, Stach et al. (2007) informed that in Poznan the higher Artemisia peak concentrations were observed from year to year $\left(>200 \mathrm{pgm}^{-3}\right)$, although the decreasing trend of annual totals was found.

\section{Conclusions}

- The highest daily pollen concentrations were achieved in Kraków in the first half of May (mainly Betula and Pinus pollen) and from the middle of July to the end of August (mainly Urtica pollen)

- The season phases (percentyles) of the spring and late-summer taxa were the most variable in the consecutive years
- The highest annual sums were noted for Urtica, Poaceae (herbaceous pollen seasons) and for Betula, Pinus, Alnus (tree pollen seasons), and the highest variability of annual totals was stated for Urtica, Populus, Fraxinus

- The negative correlation between the start and the end season dates for late-pollen seasons, especially for Ambrosia and Artemisia, were found, while for the plants that pollinate in the middle of the pollen season, the date of the season start seems not to be related to the season end

- For the most studied taxa, an increase in annual pollen totals was observed

Acknowledgments This study was supported by the project grant of the Ministry of Science and High Education No. N305 021236 (2009-2011).

Open Access This article is distributed under the terms of the Creative Commons Attribution Noncommercial License which permits any noncommercial use, distribution, and reproduction in any medium, provided the original author(s) and source are credited.

\section{References}

Alvarez-Cuesta, E., Bousquet, J., Canonica, G. W., Durham, S. R., Malling, H.-J., \& Valovirta, E. (2006). Standards for practical allergen-specific immunotherapy. Allergy, 61(Suppl. 82), 1-20.

Carinanos, P., Emberlin, J., Galán, C., \& Domingues-Vilches, E. (2000). Comparison of two pollen counting methods of slides from a Hirst type volumetric trap. Aerobiologia, 16, $339-346$.

Chłopek, K. (2007). Grass pollen (Poaceae) in the air of Sosnowiec (Poland), 1997-2006. Acta Agrobotanica, 60(2), 79-86.

D’Amato, D., Cecchi, L., Bonini, S., Nunes, C., AnnesiMaesano, I., Behrendt, H., et al. (2007). Allergenic pollen and pollen allergy in Europe. Allergy, 62(9), 976-990.

Donnelly, A., Jones, M. B., \& Sweeney, J. (2004). A review of indicators of climate change for use in Ireland. International Journal of Biometeorology, 49, 1-12.

Emberlin, J., Detandt, M., Gehrig, R., Jäger, S., Nolard, N., \& Rantio-Lehtimäki, A. (2002). Responses in the start of Betula (birch) pollen seasons to recent changes in spring temperatures across Europe. International Journal of Biometeorology, 46, 159-170.

Emberlin, J., Jäger, S., Dominguez-Vilches, E., Galán Soldevilla, C., Hodal, L., Mandrioli, P., et al. (2000). Temporal and geographical variations in grass pollen seasons in areas of Western Europe: An analysis of season dates at sites of the European pollen information system. Aerobiologia, 16, 73-379. 
Emberlin, J., Smith, M., Close, R., \& Adams-Groom, B. (2007). Changes in the seasons of the early flowering trees Alnus spp and Corylus spp in Worcester, United Kingdom, 1996-2005. International Journal of Biometeorology, 51, 181-191.

Frei, T., \& Leuschner, R. M. (2000). A change from grass pollen induced allergy to tree pollen induced allergy: 30 years of pollen observation in Switzerland. Aerobiologia, 16, 407-416.

Frey, L. (2007). Taksonomia traw. In L. Frey (Ed.), Księga polskich traw (pp. 39-76). Kraków: Instytut Botaniki im. W. Szafera, Polska Akademia Nauk.

Garcia-Mozo, H., Galán, C., Aira, M. J., Belmonte, J., Diaz de la Guardia, C., Fernández, D., et al. (2002). Modelling start of oak pollen season in different climatic zones in Spain. Agricultural and Forest Meteorology, 110, 247-257.

Jato, V., Rodríguez-Rajo, F. J., Alcázar, P., De Nuntiis, P., \& Galán, C. (2006). May the definition of pollen season influence aerobiological results? Aerobiologia, 22, 13-25.

Kasprzyk, I. (2003). Flowering phenology and airborne pollen grains of chosen tree taxa in Rzeszów (SE Poland). Aerobiologia, 19, 113-120.

Kasprzyk, I., Uruska, A., Szczepanek, K., Latałowa, M., Gaweł, J., Harmata, K., et al. (2004). Regional differentiation of the dynamics of the pollen seasons of Alnus, Corylus, Fraxinus in Poland (preliminary results). Aerobiologia, 20, 141-151.

Latałowa, M., Miętus, M., \& Uruska, A. (2002). Seasonal variations in the atmospheric Betula pollen Mount in Gdańsk (southern Baltic coast) in relation to meteorological parameters. Aerobiologia, 18, 33-43.

Madeja, J., Wypasek, E., Plytycz, B., Sarapata, K., \& Harmata, K. (2005). Quantification of airborne birch (Betula sp.) pollen grains and allergens in Krakow. Archivum Immunologiae et therapiae Experimentalis, 53, 169-174.

Myszkowska, D. (2006). Pyłek wybranych taksonów roślin w powietrzu Krakowa, 2001-2005. In E. WeryszkoChmielewska (Ed.), Pytek roslin $w$ aeroplanktonie różnych regionów Polski (pp. 21-30). Lublin: Wydawnictwo Akademii Medycznej.

Myszkowska, D., Jenner, B., Cywa, K., Kuropatwa, M., Stępalska, D., \& Piotrowicz, K. (2007). Pollen seasons of selected tree and shrub taxa in Kraków and its neighbourhood. Acta Agrobotanica, 60(2), 71-77.

Myszkowska, D., Stępalska, D., Obtułowicz, K., \& Porębski, G. (2002). The relationship between airborne pollen and fungal spore concentration and seasonal pollen allergy symptoms in Kraków in 1997-1999. Aerobiologia, 18, $153-161$.

Newnham, R. W. (1999). Monitoring biogeographical response to climate change: The potential role of aeropalynology. Aerobiologia, 15, 87-94.

Obrębska-Starklowa, B. (1977). Typologia i regionalizacja fenologiczno-klimatyczna na przykładzie dorzecza Górnej Wisły. Habilitation thesis. Drukarnia Uniwersytetu Jagiellońskiego, Kraków.

Obtułowicz, M. (1939). O nieżycie pyłkowym. Biologia Lekarska, 3, 217-249.

Obtułowicz, K., Myszkowska, D., \& Stępalska, D. (2002). The efficacy of symptomatic treatment of pollen allergy with regard to pollen concentration-introduction of a new coefficient. Allergy Clinical Immunology, 12(3), 105-109.

Obtułowicz, K., Szczepanek, K., Radwan, J., Grzywacz, M., Adamus, K., \& Szczeklik, A. (1991). Correlation between airborne pollen incidence, skin prick tests and serum immunoglobulin in allergic people in Cracow, Poland. Grana, 30, 136-141.

Obtułowicz, K., Szczepanek, K., \& Szczeklik, A. (1990). The value of pollen count for diagnosis and therapy of pollen allergy in Poland. Grana, 29, 318-320.

Orlandi, F., Sgromo, C., Bonofiglio, T., Ruga, L., Romano, B., \& Fornaciari, M. (2009). A comparison among olive flowering trends in different Mediterranean areas (southcentral Italy) in relation to meteorological variations. Theor Appl Climatol, 97, 339-347.

Piotrowska, K. (2006). Kalendarz pyłkowy dla Lublina, 1995-2000. Acta Agrobotanica, 59(1), 529-538.

Piotrowska, K., \& Weryszko-Chmielewska, E. (2006). Ambrosia pollen in the air of Lublin, Poland. Aerobiologia, 22, 151-158.

Puc, M. (2006). Ragweed and mugwort pollen in Szczecin, Poland. Aerobiologia, 22, 67-78.

Rodriguez-Rajo, F. J., Dopazo, A., \& Jato, V. (2004). Environmental factors affecting the start of pollen season and concentrations of airborne Alnus pollen in two localities of Galicia (NW Spain). Ann Agric Environ Med, 11, 35-44.

Sak-Rusek, D., Czarnobilska, E., Dyga, W., \& Obtułowicz, K. (2009). The allergic diseases of school pupils aged 7 and 16 in preventive investigations. Alergologia Immunologia, 6(1), 27-31.

Samoliński, B. (2008). Epidemiologia Chorób Alergicznych w Polsce (ECAP). Raport z badań przeprowadzonych w latach 2006-2008. Warszawa.

Seneta, W., \& Dolatowski, J. (2007). Dendrologia. Wydawnictwo Naukowe PWN: Warszawa.

Smith, M., Emberlin, J., Stach, A., Czarnecka-Operacz, M., Jenerowicz, D., \& Silny, W. (2007). Regional importance of Alnus pollen as an aeroallergen: A comparative study of Alnus pollen counts from Worcester (UK) and Poznań (Poland). Annals of Agricultural and Environmental Medicine, 14, 123-128.

Smith, M., Emberlin, J., Stach, A., Rantio-Lehtimäki, A., Caulton, E., Thibaudon, M., et al. (2009). Influence of the North Atlantic Oscillation on grass pollen counts in Europe. Aerobiologia, 25, 321-332.

Smith, M., Skjøth, C. A., Myszkowska, D., Uruska, A., Puc, M., Stach, A., et al. (2008). Long-range transport of Ambrosia pollen to Poland. Agricultural and Forest Meteorology, 148, 1402-1411.

Spieksma, F. T. M., Corden, J. M., Detandt, M., Millington, W. M., Nikkels, H., Nolard, N., et al. (2003). Quantitative trends in annual totals of five common airborne pollen types (Betula, Quercus, Poaceae, Urtica, and Artemisia), at five pollen-monitoring stations in Western Europe. Aerobiologia, 19, 171-184.

Spieksma, F. T. M., Emberlin, J., Hjelmroos, M., Jäger, S., \& Leuschner, R. M. (1995). Atmospheric birch (Betula) pollen in Europe: Trends and fluctuations in annual quantities and starting dates of the seasons. Grana, 34, 51-57. 
Stach, A. (2000). Variation in pollen concentration of most allergenic taxa in Poznań (Poland), 1995-1996. Aerobiologia, 16, 63-68.

Stach, A. (2006). Pyłek wybranych taksonów roślin w powietrzu Poznania, 2001-2005. In E. Weryszko-Chmielewska (Ed.), Pytek rostin $w$ aeroplanktonie różnych regionów Polski (pp. 31-48). Lublin: Wydawnictwo Akademii Medycznej.

Stach, A., Emberlin, J., Adams-Groom, B., Smith, M., \& Myszkowska, D. (2008). Factors that determine the severity of Betula spp. pollen seasons in Poland (Poznań and Kraków) and the United Kingdom (Worcester and London). Journal of Internal Biometeorology, 52(4), 311-321.

Stach, A., Garcia-Mozo, H., Prieto-Baena, J. C., CzarneckaOperacz, M., Jenerowicz, D., Silny, W., et al. (2007). Prevalence of Artemisia species pollinosis in Western Poland: Impact of climate change on aerobiological cal trends. Journal of Investigational Allergology and Clinical Immunology, 17(1), 39-47.

Stępalska, D., Myszkowska, D., Wołek, J., Piotrowicz, K., \& Obtułowicz, K. (2008). The influence of meteorological factors on Ambrosia pollen loads in Kraków, Poland, 1995-2006. Grana, 47, 297-304.

Stępalska, D., Szczepanek, K., \& Myszkowska, D. (2002). Variation in Ambrosia pollen concentration in Southern and Central Poland in 1982-1999. Aerobiologia, 18, 13-22.
Szczepanek, K. (1994). Pollen calendar for Kraków (southern Poland), 1982-1991. Aerobiologia, 10(1), 65-70.

Szczepanek, K. (2003). Wytwarzanie i rozprzestrzenianie spor i ziarn pyłku. In S. Dybova-Jachowicz \& A. Sadowska (Eds.), Palinologia (pp. 16-28). Kraków: Wydawnictwo Instytutu Botaniki PAN.

Weryszko-Chmielewska, E. (Ed.). (2006). Pyłek roślin w aeroplanktonie różnych regionów Polski. Lublin: Wydawnictwo Akademii Medycznej.

Weryszko-Chmielewska, E. (2007). Zakres badań i znaczenie aerobiologii. In E. Weryszko-Chmielewska (Ed.), Aerobiologia (pp. 6-10). Lublin: Wydawnictwo Akademii Rolniczej w Lublinie.

Weryszko-Chmielewska, E., \& Piotrowska, K. (2004). Airborne pollen calendar of Lublin, Poland. Annals of Agriculture and Environmental Medicine, 11, 91-97.

Weryszko-Chmielewska, E., Puc, M., \& Rapiejko, P. (2001). Comparative analysis of pollen count of Corylus, Alnus and Betula in Szczecin, Warszawa and Lublin (2000-2001). Annals of Agricultural and Environmental Medicine, 8, 235-240.

Woś, A. (1999). Klimat Polski. Warszawa: PWN.

Zając, A., \& Zając, M. (Ed.). (2001). Distribution atlas of vascular plants in Poland. Institute of Botany, Jagiellonian University and Foundation of Jagiellonian University. Kraków. 